\title{
Cytotoxic Antibodies to Cloned Rat Islet Cells in Serum of Patients with Diabetes Mellitus
}

\author{
George S. Eisenbarth, Mary Ann Morris, and Richard M. Scearce, \\ Departments of Medicine and Pediatrics, Duke University Medical Center, \\ Durham, North Carolina 27710
}

\begin{abstract}
A B S T R A C T We have found complement-dependent cytotoxic antibodies in the serum of 8 of 24 patients with insulin-dependent diabetes mellitus using a ${ }^{51} \mathrm{Cr}$ cytotoxicity assay with monolayers of cloned rat islet cells (clones RINm 5F and RINm 14B). In contrast, complement-dependent cytotoxicity with ${ }^{51} \mathrm{Cr}$ release $>24 \%$ was not found with sera from 34 controls or from 5 patients with polyglandular failure without diabetes, and was present in only 1 serum out of 12 from patients with insulin-independent diabetes mellitus. The prevalence of antibodies appears to decrease with duration of insulin-dependent diabetes, and in one patient studied, cytotoxic antibodies were present at the time of diagnosis of diabetes. Cytotoxicity is independent of insulin synthesis, as evidenced by the linear correlation of cytotoxicity of sera for the insulin-producing clone RINm $5 \mathrm{~F}$ and the somatostatin-producing clone RINm 14B. The present study identifies nonspecies-specific cytotoxic antibodies in the serum of patients with diabetes mellitus, and the assay used should facilitate studies of humoral immunity in the pathogenesis of diabetes mellitus.
\end{abstract}

\section{INTRODUCTION}

Using indirect immunofluorescent techniques on frozen (1) or Bouin's fixed sections of human pancreas (2), autoantibodies to pancreatic islet cells have been found in the sera of patients with insulin-dependent diabetes. Recently, a subset of such antibodies has been shown to fix complement (3). These antibodies decrease in prevalence as a function of the duration of diabetes, and in a number of instances have been detected before the development of disease. It appears that such antibodies react with a cytoplasmic component of islet cells (3). How such antibodies reacting with the cytoplasm may be pathogenic is not clear,

Received for publication 22 July 1980 and in revised form 1 October 1980. though it is possible that such antibodies reacting with damaged islet cells may enhance inflammatory processes within islets. Serum from insulin-dependent diabetic patients also contains antibodies to the surface of islet cells. Using indirect immunofluorescence, MacLaren and co-workers (4) found antibodies to the surface of a cultured human insulinoma in 34 out of 39 diabetic patients. Lernmark et al. (5), using a similar technique, have reported the occurrence of antibodies directed against the cell surface of rat islet cells. Rittenhouse and co-workers (6) have described nonspecies-specific factors in the sera of patients with diabetes that are cytotoxic to guinea pig islets. These and other studies have contributed to the development of the hypothesis that autoimmune phenomena are of importance in the pathogenesis of insulin-dependent diabetes mellitus.

Studies of the immunochemistry of anti-islet antibodies and isolation of islet cell antibodies have been hindered by the difficulty in obtaining large quantities of islet cells. Permanent cell lines expressing relevant cell-surface antigens would facilitate such studies. Using monoclonal antibodies directed against cellsurface antigens expressed by the RINm rat islet cell line, we have found that these cultured cells express many antigens (including differentiation antigens) that are present on normal rat pancreatic islet cells (7). Furthermore, these cells, when grown in monolayer culture, can be used in a sensitive ${ }^{51} \mathrm{Cr}$ cytotoxicity assay. In the present study we have therefore assayed serum from patients with diabetes mellitus and from controls for the presence of cytotoxic antibodies to RINm cells.

\section{METHODS}

Cell culture. RINm cells, RINm clone 14B, and RINm clone $5 \mathrm{~F}$ were obtained from Drs. Adi Gazdar, Herbert Oie, and W. Chick (8). RINm5F cells synthesize insulin, and RINm14B cells synthesize somatostatin. These cell lines were derived from the RISL-transplantable NEDH rat islet 
cell tumor. Before use in the cytotoxicity assay, cells were cultured as monolayers in RPMI 1640 medium supplemented with $10 \%$ heat-inactivated fetal calf serum $\left(56^{\circ} \mathrm{C}\right.$ for $\left.30 \mathrm{~min}\right)$ in T75 Falcon flasks. Monoclonal antibody F41 6B2 was synthesized by a hybrid cell line derived from the fusion of spleen cells of a mouse immunized with RINm cells and the P3x63 mouse myeloma cell line (7). This mouse antibody is cytotoxic to RINm cells, and large amounts of monoclonal antibody have been produced by growing the F41 6B2 cell line as ascites tumors in Balb/C mice.

Cytotoxicity assay. Serum was prepared for assay by diluting in Dulbecco's phosphate-buffered saline $(\mathrm{PBS})^{1}$ $(1: 1, \mathrm{vol} / \mathrm{vol})$ heating at $56^{\circ} \mathrm{C}$ for $30 \mathrm{~min}$ and absorbing overnight with $1 \mathrm{mg}$ of rat liver powder (N. L. Cappel Laboratories, Inc., Cochranville, $\mathrm{Pa}$.) per $400 \mu \mathrm{l}$ of diluted serum. Cells for assay were obtained by incubation $(5 \mathrm{~min}$ at room temperature) with $5 \mathrm{ml}$ of $0.025 \%$ trypsin (Worthington Biochemical Co., Freehold, N. J.) in Dulbecco's PBS. The resulting cell suspension was centrifuged at $500 \mathrm{~g}$, the supernate discarded, and the cells resuspended in $10 \mathrm{ml}$ of RPMI 1640 medium supplemented with $10 \%$ heat-inactivated $\left(56^{\circ} \mathrm{C}\right.$ for $\left.30 \mathrm{~min}\right)$ fetal calf serum $\left(2-5 \times 10^{6}\right.$ cells $\left./ 50 \mathrm{ml}\right)$. $0.1 \mathrm{ml}$ of the cell suspension was added to each well of a 96-well microculture plate and cultured for 48-96 h before assay. 4-24 $\mathrm{h}$ before the assay, medium was removed from each well, and $0.1 \mathrm{ml}$ RPMI medium containing $10 \%$ heatinactivated fetal calf serum and $75,000 \mathrm{cpm}$ of ${ }^{51} \mathrm{Cr}$ (counting efficiency $70 \%$ ) was added. Immediately before assay, the plate was inverted onto a utility wipe and the wells were washed three times with $150 \mu$ l of RPMI medium. For the cytotoxicity assay, $10 \mu \mathrm{l}$ of RPMI medium was added to each well followed by $50 \mu \mathrm{l}$ of a 1:1 (vol/vol) dilution (in PBS) of test serum. After incubation with serum at $37^{\circ} \mathrm{C}$ for $30 \mathrm{~min}$ $60 \mu \mathrm{l}$ of a $1: 2(\mathrm{vol} / \mathrm{vol})$ dilution of rabbit complement in PBS with $\mathrm{Ca}$ and $\mathrm{Mg}$ was added, and after $30 \mathrm{~min}$ at $37^{\circ} \mathrm{C}$, an aliquot of the medium was harvested with a micropipette or Titertek harvesting filter (Flow Laboratories, Rockville, $\mathrm{Md}$.) and counted in a gamma counter. Total ${ }^{51} \mathrm{Cr}$ incorporation was determined by adding $50 \mu \mathrm{l}$ of $0.3 \%$ Triton X-100. Release in the absence of antibody (PBS rather than serum) was $<10 \%$ of total ${ }^{51} \mathrm{Cr}$ release. Specific cytotoxicity was calculated as follows:

\section{Specific cytotoxicity}

$$
=\frac{{ }^{51} \mathrm{Cr} \text { release with test serum }-{ }^{51} \mathrm{Cr} \text { release with PBS }}{{ }^{51} \mathrm{Cr} \text { release with Triton }-{ }^{51} \mathrm{Cr} \text { release with PBS }} .
$$

Patient population. Serum was obtained from nonhospitalized healthy individuals (control), patients with a history compatible with insulin-dependent diabetes mellitus (ketoacidosis, onset of diabetes mellitus less than age 40, usually less than age 20 , receiving insulin), patients with a history compatible with insulin-independent diabetes mellitus (abnormal glucose tolerance test with fasting glucose $>140 \mathrm{mg} \%$, no history of ketoacidosis, treatment with diet, or oral hypoglycemic agents for $>1 \mathrm{yr}$ ), and patients with polyglandular failure without diabetes (primarily Addison's disease and autoimmune thyroid disease [9]).

$\mathrm{NH}_{4} \mathrm{SO}_{4}$ precipitation. A $1: 1(\mathrm{vol} / \mathrm{vol})$ dilution of serum was incubated in a $45 \%$ saturated $\mathrm{NH}_{4} \mathrm{SO}_{4}$ solution ( $\mathrm{pH} 7.2$ ) at room temperature for $30 \mathrm{~min}$; the precipitate was washed with $45 \%$ saturated $\mathrm{NH}_{4} \mathrm{SO}_{4}$ and then redissolved in PBS.

\footnotetext{
${ }^{1}$ Abbreviation used in this paper: PBS, phosphate-buffered saline.
}

Insoluble material was removed by centrifugation at $1,000 \mathrm{~g}$ for $15 \mathrm{~min}\left(4^{\circ} \mathrm{C}\right)$ and the supernate was incubated with $40 \%$ saturated $\mathrm{NH}_{4} \mathrm{SO}_{4}$ for $30 \mathrm{~min}$ (room temperature). The precipitate was then washed once with $40 \%$ saturated $\mathrm{NH}_{4} \mathrm{SO}_{4}$, redissolved in $\mathrm{PBS}$, and then dialyzed against PBS (50:1) three times.

Incubation of serum with anti-human immunobeads. Serum diluted in PBS $(1: 2, \mathrm{vol} / \mathrm{vol})$ or the redissolved $\mathrm{NH}_{4} \mathrm{SO}_{4}$ precipitate was incubated with $2.2 \mathrm{mg} / \mathrm{ml}$ of rabbit anti-human IgG immunobeads (specific for $\gamma$-chains), rabbit anti-human IgM immunobeads (specific for $\mu$-chains), or 1.1 $\mathrm{mg} / \mathrm{ml}$ of both anti-IgG anti-IgM immunobeads (Bio-Rad Laboratories, Richmond, Calif.) for $60 \mathrm{~min}$ at $4^{\circ} \mathrm{C}$, after which the immunobeads were removed by centrifugation and the supernates tested for cytotoxicity.

\section{RESULTS}

Prevalence of cytotoxic antibodies. As illustrated in Fig. 1, strongly cytotoxic sera $\left({ }^{51} \mathrm{Cr}\right.$ release $\left.>24 \%\right)$ were obtained almost exclusively from patients with insulin-dependent diabetes mellitus. Serum from onethird $(8 / 24)$ of patients with insulin-dependent diabetes

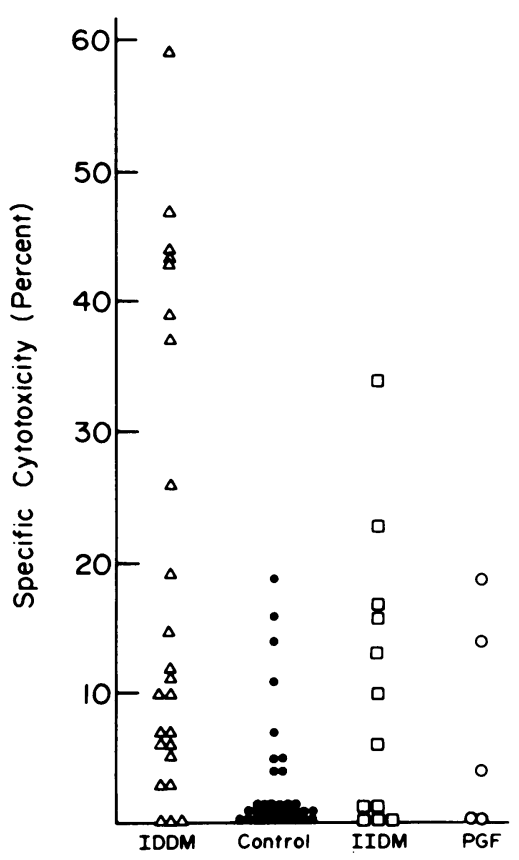

FIGURE $1{ }^{51} \mathrm{Cr}$ release from RINm $5 \mathrm{~F}$ monolayers (percent specific cytotoxicity) in the presence of rabbit complement and heat-inactivated absorbed serum from patients with insulin-dependent diabetes mellitus $(\triangle)$, normal individuals $(\bullet)$, patients with insulin-independent diabetes ( $\square$ ), and patients with polyglandular failure without diabetes mellitus (O). Specific cytotoxicity was calculated from ${ }^{51} \mathrm{Cr}$ release as described in Methods. Mean cytotoxicity was significantly greater in the insulin-dependent diabetes mellitus group $(19.0 \pm 3.8)$ compared with controls $(2.7 \pm 0.9, P<0.01)$ and insulin-independent diabetes group $(9.7 \pm 3.1, P<0.05)$. 
was strongly cytotoxic, whereas serum from 0 of 34 normal individuals, 0 of 5 patients with polyglandular failure without diabetes, and only 1 of 12 patients with insulin-independent diabetes released $>24 \%$ of incorporated ${ }^{51} \mathrm{Cr}$. In addition to the quantitative index of cytotoxicity provided by ${ }^{51} \mathrm{Cr}$ release, the killing of cells in monolayer culture was apparent with phasecontrast microscopy (Fig. 2). Cytotoxicity depended on incubation with both antibody and rabbit complement (Fig. 3). In the absence of complement there was essentially no cytotoxicity.

Fig. 4 plots the cytotoxicity of serum from patients with insulin-dependent diabetes mellitus vs. the duration of diabetes. All strongly cytotoxic sera were obtained from individuals within $6 \mathrm{yr}$ of diagnosis of diabetes. Serum from one patient, which was strongly cytotoxic, was obtained at the time of initial diagnosis of diabetes.
Antibody characterization. Because cytotoxicity was rapid, complement dependent, and required small amounts of diluted serum, it seemed likely that the cytotoxicity of serum from patients with insulin-dependent diabetes was antibody mediated. To test this hypothesis, immunoglobulin from one cytotoxic serum was precipitated twice by ammonium sulfate precipitation (see Methods) and then redissolved in twice its original volume of PBS and dialyzed extensiely. As shown in Table I, this partially purified antibody preparation was cytotoxic. Furthermore, a 90 -min incubation with a combination of anti-human IgG and anti-human IgM immunobeads reduced specific cytotoxicity of this antibody preparation from 45 to $11 \%$ (Table I). The ability of incubation with immunobeads to reduce serum cytotoxicity was also tested with two cytotoxic serums and one noncytotoxic serum without prior ammonium sulfate precipitation (Table
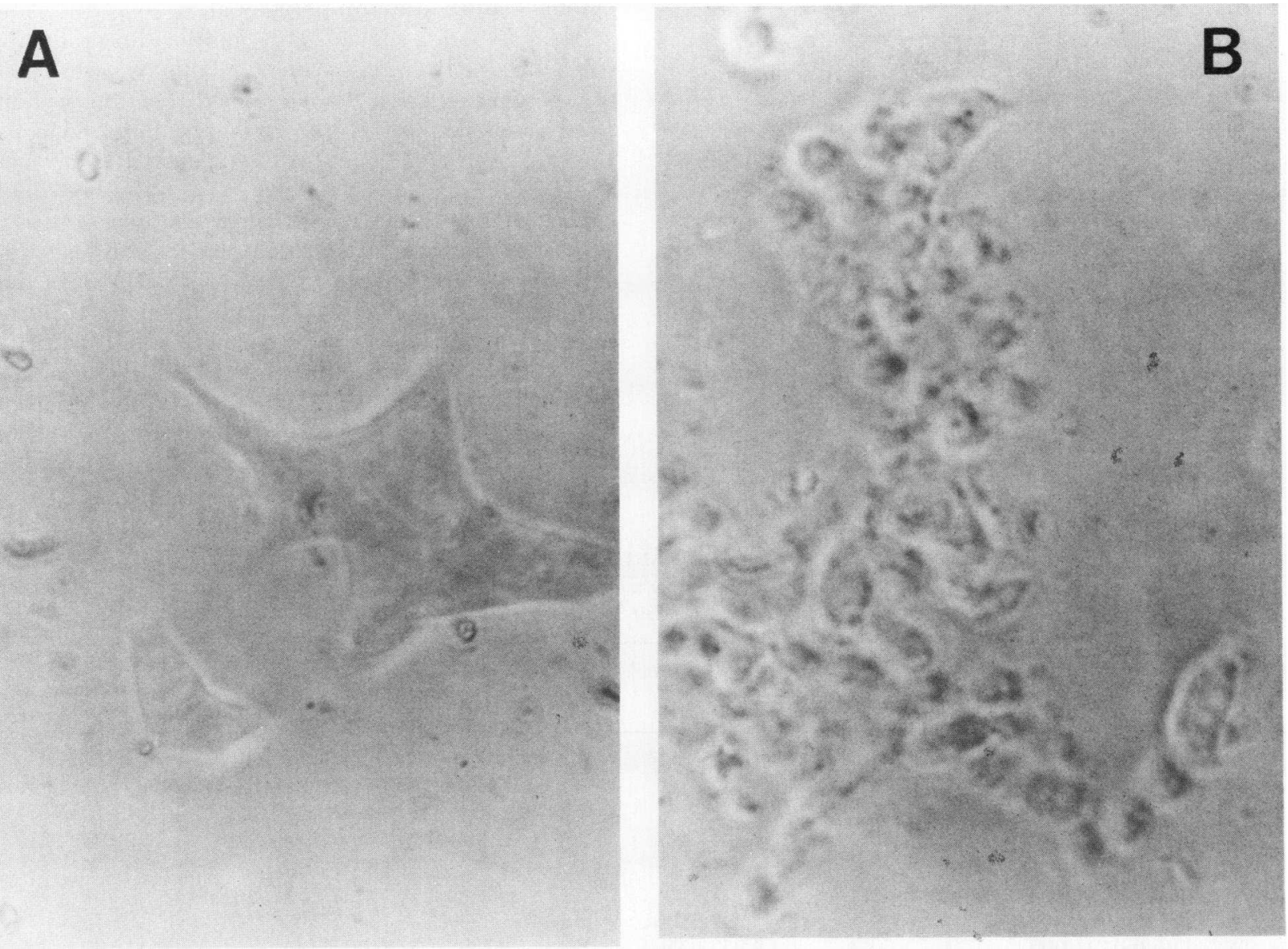

FIGURE 2 Phase-contrast photomicrograph of a monolayer of RINm5F cells at the completion of a cytotoxicity assay. Cells were incubated with a positive serum $\left({ }^{51} \mathrm{Cr}\right.$ cytotoxicity assay) from a patient with insulin-dependent diabetes (panel B) or serum from a patient with insulin-dependent diabetes negative by the ${ }^{51} \mathrm{Cr}$ cytotoxicity assay (panel $\mathrm{A}$ ). 


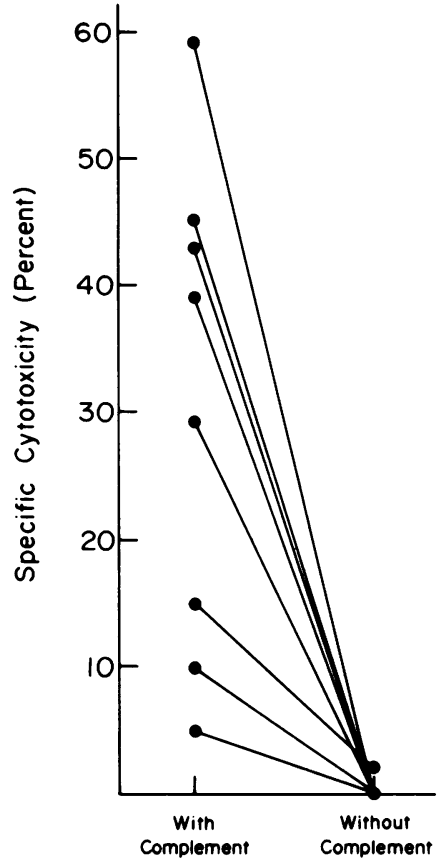

FIGURE 3 Specific cytotoxicity of serum from patients with insulin-dependent diabetes mellitus in the presence or absence of rabbit complement.

I). For patient 2 , both anti-IgM and anti-IgG immunobeads reduced cytotoxicity, though anti-IgG beads were more effective. For patient 3 , only anti-IgG beads reduced cytotoxicity. As expected, ${ }^{51} \mathrm{Cr}$ release of a negative serum and PBS controls were not significantly altered by prior incubation with immunobeads. The cytotoxicity of the mouse monoclonal

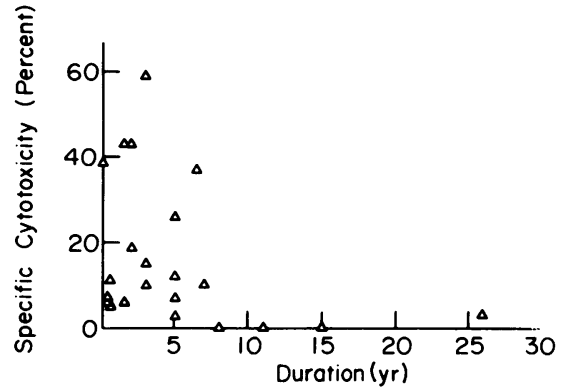

FIGURE 4 Specific cytotoxicity of serum from 22 patients with insulin-dependent diabetes mellitus vs. the duration of recognized diabetes.

antibody $6 \mathrm{~B} 2$, which does not react with anti-human immunobeads, was unaffected by the immunobeads. Inhibition of cytotoxicity in some patients by both anti-IgG and anti-IgM immunobeads suggests that the cytotoxic antibodies are polyclonal.

Because both a somatostatin- and insulin-producing subclone of RINm cells were available, we were able to test whether the cytotoxic effect of serum was dependent on insulin synthesis by the cultured cells. Fig. 5 plots specific cytotoxicity against RINm clone $5 \mathrm{~F}$ cells ( $x$-axis, insulin-producing) vs. cytotoxicity against RINm clone 14B cells (somatostatin-producing). The cytotoxicities against the two cell lines were significantly correlated $(r=0.65, P<0.01)$. Sera that resulted in $>24 \%$ release of ${ }^{51} \mathrm{Cr}$ from the $5 \mathrm{~F}$ cell line released $>20 \%$ of clone $14 \mathrm{~B}$-incorporated ${ }^{51} \mathrm{Cr}$. To determine whether serum from diabetic patients is cytotoxic to nonislet tumors, we tested the effect of three positive sera and two negative sera on the rat $\mathrm{GH}_{3}$ pituitary cell line and the neuroblastoma-glioma

TABLE I

Inhibition of the Cytotoxicity of Serum from Patients with Insulin-dependent Diabetes Mellitus by Rabbit Anti-human Immunobeads

\begin{tabular}{lcccc}
\hline \multicolumn{1}{c}{ Serum } & No additions & $\begin{array}{c}\text { Anti-IgG } \\
(2.2 \mathrm{mg} / \mathrm{ml})\end{array}$ & $\begin{array}{c}\text { Anti-IgM } \\
(2.2 \mathrm{mg} / \mathrm{ml})\end{array}$ & $\begin{array}{c}\text { Anti-IgG } \\
\text { and anti-IgM } \\
(1.1 \mathrm{mg} / \mathrm{ml})\end{array}$ \\
\hline Patient 1 ( $\mathrm{NH}_{4} \mathrm{SO}_{4}$ precipitation) & $4,743 \pm 178^{*}$ & $3,958 \pm 508$ & $3,903 \pm 124 \ddagger$ & $1,895 \pm 213 \ddagger$ \\
Patient 2 & $9,486 \pm 168$ & $2,343 \pm 823 \ddagger$ & $6,023 \pm 247 \ddagger$ & $5,095 \pm 868 \ddagger$ \\
Patient 3 & $2,176 \pm 251$ & $1,301 \pm 225 \ddagger$ & $2,421 \pm 469$ & $1,811 \pm 12$ \\
Patient 4 (negative) & $1,191 \pm 162$ & $1,109 \pm 202$ & $869 \pm 66$ & $872 \pm 203$ \\
PBS & $977 \pm 72$ & $907 \pm 67$ & $789 \pm 153$ & $774 \pm 56$ \\
Mouse monoclonal antibody F41 6B2 & & & & $5,713 \pm 559$ \\
$\quad$ Diluted 1:100 & $6,248 \pm 1061$ & $5,597 \pm 572$ & $5,877 \pm 1355$ & $3,511 \pm 90$ \\
$\quad$ Diluted 1:1,000 & $2,953 \pm 350$ & $2,937 \pm 139$ & $3,078 \pm 2$ & \\
\hline
\end{tabular}

Results are the mean $\pm S E M$ of triplicate determinations of ${ }^{51} \mathrm{Cr}$ release expressed in counts per minute.

* In this experiment, Triton $\mathrm{X}-100$ released $8,367 \pm 117 \mathrm{cpm}$.

$\$ P<0.05$ relative to no additions. 


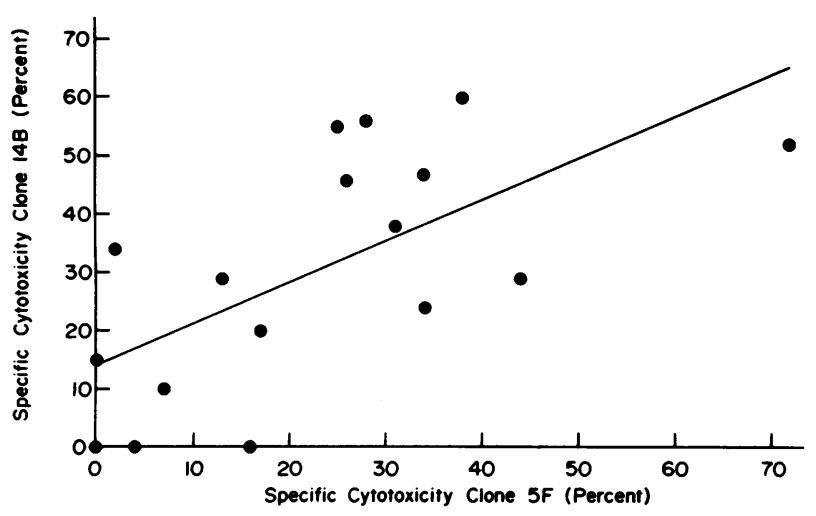

FIGURE 5 Specific cytotoxicity of individual sera from patients with insulin-dependent diabetes mellitus for RINm clone 14B (somatostatin-producing) and RINm clone $5 \mathrm{~F}$ (insulin-producing).

hybrid cell line 108-15. None of the sera were significantly cytotoxic (specific cytotoxicity $<6 \%$ for all sera).

\section{DISCUSSION}

A major hindrance to detailed study of anti-islet antibodies in patients with insulin-dependent diabetes mellitus has been the difficulty in obtaining adequate quantities of islet cells. Several recent studies, particularly studies employing monoclonal antibody reagents, have revealed that continuous cell lines often express cell-surface differentiation antigens which are present on the normal cells from which the cell line or tumor originated $(10,11)$. Our own studies of monoclonal antibodies to RINm cells indicate that these cells express many antigens present on normal islet cells (7). The purpose of the present study was to determine whether serum from patients with insulin-dependent diabetes mellitus contains antibodies cytotoxic to these RINm cells. We have found that sera from one-third (8/24) of patients with insulindependent diabetes mellitus are strongly cytotoxic to RINm cells. We do not know whether the absence of cytotoxic antibodies in some patients with insulindependent diabetes reflects the fact that our assay detects only species-nonspecific antibodies. Several lines of evidence indicate that the cytotoxic factor(s) are antibodies: cytotoxicity is rapid, complement dependent, resistant to heat inactivation at $56^{\circ} \mathrm{C}$ for $30 \mathrm{~min}$, precipitable by $40 \% \mathrm{NH}_{4} \mathrm{SO}_{4}$, nondialyzable, and most importantly, removed by anti-human immunobeads. Normal individuals, patients with polyglandular failure without diabetes, and patients with insulin-independent diabetes mellitus have a much lower prevalence of cytotoxic antibodies to RINm cells.
The duration of insulin-dependent diabetes mellitus appears to influence the prevalence of antibodies. All positive sera detected thus far have been obtained from patients with a duration of diabetes of $<6 \mathrm{yr}$.

Initial characterization of the cytotoxic antibodies to RINm cells suggests that they are polyclonal (reaction with both anti-IgM and anti-IgG immunobeads). Cytotoxicity appears to be independent of insulin synthesis by the cell lines. Both a somatostatin(RINm clone 14B) and an insulin-producing (RINm 5F) clone of RINm cells are killed by serum from patients with insulin-dependent diabetes mellitus. Cytotoxicity of individual sera for the two cell lines is positively correlated. This lack of specificity for insulincontaining cells is similar to the antibodies described by Bottazo and co-workers $(1,3)$, in that all islet cells appear to react with these antibodies even though in insulin-dependent diabetes mellitus only beta cells are destroyed. The cytotoxic antibodies we are studying may similarly lack specificity for beta cells. It is possible, however, that the somatostatin-producing clone $14 \mathrm{~B}$, though it does not synthesize insulin, carries antigens expressed primarily on beta cells on its surface.

It is not known whether the antibodies we have detected in the serum of patients with insulin-dependent diabetes mellitus are pathogenic. The existence of these antibodies, and of anti-islet antibodies detected by other methods, may be a reflection rather than a cause of beta cell damage. Nevertheless, the cytotoxic nature of these antibodies certainly raises the possibility that they contribute to beta cell damage. In addition to direct complement-mediated cytotoxicity, such antibodies may be important for antibody-dependent cell-mediated cytotoxicity. The ready availability of these islet cell lines coupled with the speed and quantitative nature of the monolayer ${ }^{51} \mathrm{Cr}$ assay should facilitate studies to answer this question.

\section{ACKNOWLEDGMENTS}

We thank Rena Wethington for her expert secretarial assistance.

This study was supported in part by National Institutes of Health grant AM 25778-01, by a Basil O'Connor Starter Grant, and by a grant (M01 FR 30) from the Clinical Research Center Branch Division of Research Facilities and Resources.

\section{REFERENCES}

1. Bottazo, G. F., F. Christensen, and D. Doniach. 1974. Islet-cell antibodies in diabetes mellitus with autoimmune polyendocrine deficiencies. Lancet. II: 1279-1283.

2. Dobersen, M., A. M. Bell, A. B. Jenson, A. L. Notkins, and F. Ginsberg-Fellner. 1979. Detection of antibodies to islet cells and insulin with paraffin-embedded pancreas as antigens. Lancet. II: 1078. 
3. Bottazo, G. F., B. M. Dean, A. N. Gorsuch, A. G. Cudworth, and D. Doniach. 1980. Complement-fixing islet-cell antibodies in type-I diabetes: possible monitors of active beta cell damage. Lancet. I: 668-672.

4. MacLaren, N. K., S. Huang, and J. Fogh. 1975. Antibody to cultured human insulinoma cells in insulin-dependent diabetes. Lancet I: 997-999.

5. Lernmark, A., Z. Freedman, C. Hofmann, A. H. Rubenstein, D. F. Steiner, R. L. Jackson, R. J. Winter, and H. S. Traisman. 1978. Islet-cell-surface antibodies in juvenile diabetes mellitus. $N$. Engl. J. Med. 229: 375380.

6. Rittenhouse, H. G., D. L. Oxender, S. Pek, and D. Ar. 1980. Complement-mediated cytotoxic effects on pancreatic islets with sera from diabetic patients. Diabetes. 29: 317-322

7. Eisenbarth, G. S., H. K. Oie, A. F. Gazdar, W. L. Chick, and R. Mittler. 1980. Production of lymphocyte hybridoma antibodies reacting with rat islet cell surface molecules. 62nd Annual Meeting of the Endocrine Society. Abstr. 557.

8. Gazdar, A. F., W. L. Chick, H. K. Oie, H. L. Sims, D. L. King, G. G. Weir, and V. Lauris. 1980. Continuous clonal insulin and somatostatin secreting cell lines established from a transplantable rat islet cell tumor. Proc. Natl. Acad. Sci. U. S. A. 77: 3523.

9. Eisenbarth, G. S., P. W. Wilson, F. Ward, C. Buckley, and H. Lebovitz. 1979. The polyglandular failure syndrome: disease inheritance, HLA type and immune function. Ann. Int. Med. 91: 528-533.

10. Reinherz, E. L., P. C. Kung, G. Goldstein, and S. F. Schlossman. 1979. Separation of functional subsets of human $\mathrm{T}$ cells by a monoclonal antibody. Proc. Natl. Acad. Sci. U. S. A. 76: 4061.

11. Eisenbarth, G. S., B. F. Haynes, J. A. Schroer, and A. S. Fauci. 1980. Production of monoclonal antibodies reacting with peripheral blood mononuclear cell surface differentiation antigens. J. Immunol. 124: 1237-1244. 